best trees of this species in the world, rising to 160 feet, especially in the north of the Rapti Valley, in what is now the Mahendra National Park. The sal are being exploited by the Forest Department only in the east towards Hitaura. At present there is no exploitation west of Debichor, except some cutting by new settlers.

Most if not all of the sal forests are under the jurisdiction of the Forest Department, and are regarded as Reserved Forests. Unfortunately, however, it appears that the boundaries of some of these Reserved Forests have not been clearly demarcated, and unauthorized persons are said to be settling in parts of them with the usual accompaniment of felling and burning for cultivation and grazing. If this is true, it deserves the urgent attention of the authorities, especially as there are so many parts of these forested hills which, forming the catchments of the streams and rivers, need careful conservation in order to avoid soil erosion and desiccation.

\title{
V. Administrative and Political
}

Administration will be considered only as far as the rhinoceros and its preservation are concerned. Three different divisions of the Forest Department are involved. The Rapti Valley is under the Divisional Forest Officer of Chitawan residing at Hitaura; the Nawalpur area (west of the Narayani river) is under the D.F.O. of that district residing at Parasi, a journey of some distance from the rhinoceros area with no roads for travelling; the Reu Valley is under the D.F.O. of Birganj. From the rhinoceros preservation aspect it is unfortunate that this area of Nepal should fall under the jurisdiction of three different D.F.O.s, under two separate Circle Conservators, with no means of communication between them except via Katmandu. The D.F.O., Chitawan, residing at Hitaura, is in charge of the whole Rhinoceros Protection Department which operates in all the three areas; but he is unable officially to visit the Nawalpur or the Reu Valley areas except by arrangement with the D.F.O. of the district concerned. All this is not a criticism of the Forest Department : it merely states the position as it happens to be to-day. The Narayani river is possibly too great a physical barrier for both sides of it to be under one D.F.O.

Poaching of Rhinoceros.

The Rhinoceros Protection Department, the personnel of which has already been given, mans 42 chowkis (posts), 26 in 
the Chitawan area, nine in the Reu Valley, and seven in Nawalpur. Poaching, as has been said, was probably at its peak during 1951. Accounts differ as to the intensity of poaching during the years 1952-58 : some people informed me that the position was static, becoming no better and no worse, while others said that during the last three years there had been a slight improvement. Probably official statistics do not give a true picture of the actual amount of poaching during any particular year.

I was told that in 1958,60 rhinoceros were officially listed as poached : 52 in Chitawan, 6 in Reu Valley and 2 in Nawalpur. Of these 60 rhinoceros killed by poachers, 24 horns were recovered, and 13 persons arrested and gaoled. In 1959, twelve cases had been detected by the end of March-Chitawan 6, Reu Valley 2, and Nawalpur 4. Of these eight horns had been recovered and seven men arrested.

I had discussion with many people, particularly with the Divisional Forest Officer of Chitawan, who had been for four years in charge of that division, and with Captain Gyan Bahadur Basnayt who had been for two years in charge of the Rhinoceros Protection Department, and there appears to be no evidence of any real organization behind the poachers. Most of the poachers of the Nawalpur area are said to come from the hills, while many of the poachers of Reu Valley and Chitawan come from the south, including India. Some of the poachers are also said to be new settlers from the hills in the Rapti Valley, Magars, Gurungs and others. The Tharus, "plains Nepalis" and original inhabitants of this area, are mostly simple and innocent folk, and are not believed to be involved to any great degree in the poaching of rhinoceros.

Most of the rhinoceros poachers in Nepal take refuge first of all in the hills, and then make their way to India, where the horns probably pass through the port of Calcutta to the Far East, particularly to China. The possession and sale of rhinoceros produce is illegal in India-if the place of origin is Bengal or Assam. But if the origin is Nepal, it is probable that its transit through and export from India would not be considered illegal under existing laws and rules. I therefore recommended, while in Katmandu, that the Government of Nepal should try to effect greater co-ordination of protective measures with the Government of India, in order to prevent this traffic. I now suggest also that the Excise Posts on the India-Nepal border should be kept constantly on the watch for the same purpose. 


\section{Development.}

The last bridges and causeways of the fine gravelled motor road from Hitaura in the east to Bharatpur and Narayangarh in the west are nearing completion. Apart from this there are no all-weather roads. In the dry weather (November to May) all villages and even isolated houses are connected by bullockcart tracks which are motorable for jeeps and other highclearance vehicles.

Since 1955 the Rapti Valley Multi-Purpose Development Project has opened up 531 square miles of grassland, formerly the home of rhinoceros and other wild life, for 12,000 human settlers, mostly from the hills (see Map No. 2). The implementation of the proposal to settle a further 25,000 persons in the Rapti Valley, combined with the influx of unauthorized settlers, if allowed to continue at its present rate, would mean that hardly any part of this once famous big-game preserve will be left for wild life.

\section{The Mahendra National Park.}

In its present size and shape, this national park contains about 50 square miles of hills and almost virgin sal forest, with a few kholas which are dried up in their middle reaches from March till June, and about 18 square miles of mixed evergreen and deciduous forest and grassland with plenty of water in the kholas and swamps.

There are villagers with their houses, cultivations and cattle at Narayangarh, Tikoli, Jirwan and Jurpani, who still have to move from the national park to alternative sites, with promised assistance from Government. The D.F.O. informed me that he was experiencing some difficulty in enforcing this order, and that the matter was urgent in view of the approaching season for seed-sowing. While I was there the Tikoli villagers expressed their willingness to leave the park area if they were given some of the areas to be re-settled nearby. I duly passed on this information to the authorities on my return to Katmandu.

Necessary additions to the Park.-North of Narayangarh up to Deoghat, the road runs along the river bank from which the mountain and river scenery is very beautiful. When I was there the red-flowering bush Woodfordia floribunda was in full bloom, as were several flowering trees; and the kusum tree, Schleichera trijuga, was in new leaf, shimmering in pale mahogany-all these as well as the sal trees in their transition stage from old to new foliage added to the beauty of the scene. But the majestic 
and unspoiled sal-forested mountains on the opposite bank west of the Narayani and north of the confluence of the rivers Kali Gandaki and Mershiandi, although they contain numbers of gaur, deer and other wild life, have not been included in the national park. As these parts are mountain and virgin forest almost totally unoccupied by human settlers, they would make a very fine addition to the park without the difficulty of removing human inhabitants.

South of the park, from where the new road forms the southern boundary at Tikoli, there is a four to six mile wide strip of comparatively unspoilt sal forest and grassland along the Khagri Khola stream down to the Rapti river, where the majority of the rhinoceros are. This strip forms a natural corridor for local seasonal migration of rhinoceros and other animals-but it has not been included in the park.

Without these two additions-the southward corridor for wild life movement along the Khagri Khola to and from the Rapti, being far the more important-the national park is not a viable ecological unit. But if this corridor be included, then it is only one step further to extend it southwards, to include both some of the best rhinoceros country south of the Rapti river and also the upper reaches of the Reu Valley. If this were done, a large percentage of Nepal rhinoceros population would be included in the national park (see Map No. 3). A further advantage of this north-south extension, fully protected under national park rules, would be that wild life could move into it, as the land to the east and west becomes occupied by settlers.

The "Wild Life Sanctuary" which the Government of Nepal proposes to establish south of the Mahendra National Park (see Map 2) cannot be regarded as a potentially true sanctuary, for a considerable amount of it is already under human occupation, cultivation or grazing. Moreover, it is proposed in some quarters that this area be a sanctuary for ten years only, after which it is to be opened up again as shooting blocks. Thus during the ten years as a "sanctuary" it would merely have the dubious status of shooting blocks temporarily closed to shooting. If the best and unspoilt portion of this proposed sanctuary were added to the present national park in order to make a viable unit, then after allowing for reasonable belts of country on either side, as buffer belts where grazing and firewood or thatch cutting are allowed, but in which no settlement or shooting except bona fide crop protection is permitted, the rest of the area might be opened as shooting blocks under 
strict control with full protection for rhinoceros and other rare species.

\section{Shooting Blocks and Kings Reserve.}

The area north of the Rapti at its eastern end, which the Government proposes should become "Shooting Blocks" consists mainly of foothills of the Mahabharat Range, and is under sal forest. The area south of the Rapti proposed as "King's Reserve" is part of the Churia Range, and also forested with sal. Both these propositions appear reasonable (see Map No. 2). They contain a few rhinoceros at their western extremities, under the protection of the Rhinoceros Protection Department.

A project believed to be in the blue-print stage is to divert the water of the Khagri Khola from a point about one mile north of Tikoli in the Mahendra National Park, and also the water of certain other streams in the vicinity, to irrigate part of the newly-settled grassland south of Bharatpur. If this were done, some of the rhinoceros area in the south of the present Mahendra National Park would dry up. Moreover, the only stream in the "corridor" needed for extending the present park southwards to the Rapti river, would cease to flow in the dry weather. This project is a serious threat to nature and wild life preservation; it is to be hoped that it will be shelved or modified.

\section{General Account of the Survey}

After a brief halt in Calcutta to discuss with Dr. Roonwal (Director of the Zoological Survey of India and SecretaryGeneral of the Indian Board for Wild Life) ways of assisting Nepal to stop any possible traffic of rhinoceros produce through India, I arrived at Katmandu by air on 15th March. There I spent six days before going into camp in the rhinoceros areas, which are a day's journey by road. This period was very usefully employed in making contact with officials and nonofficials, and in obtaining information of every description. These contacts included: General Kiran, S.J.B.R. (Shumshere Jung Bahadur Rana), who is the present authoritative and acknowledged leader in all matters pertaining to sport and wild life in Nepal; Field Marshal Kaiser, S.J.B.R., who, though he has not visited the rhinoceros area since 1933, has a vast store of knowledge of shikar and natural history; Mr. Balarama Paul Baidya, Chief Forest Officer; Major Lok Bikram, in charge of elephants (Government and others) ; Captain Tej Jung Thapa, Circle Conservator; Colonel and Mrs. Proud of the 